\title{
CCL8 Gene
}

National Cancer Institute

\section{Source}

National Cancer Institute. CCL8 Gene. NCI Thesaurus. Code C24787.

This gene is involved in the modulation of immune functions. 